\title{
Transformation Islamic Education In Indonesia
}

\author{
Nur Syahid \\ IAI Al Khoziny Buduran Sidoarjo, Indonesia
}

\begin{abstract}
Islamic boarding school, in its dynamic is regarded to have its own identity, which is termed with subculture by KH. Abdurrahman Wahid. Honestly, it must be admitted that there is a certain tradition that grows and thrives in Islamic boarding school society. However, it is not a reality outside of Islamic boarding school society. Undeniably, when the outside environment begins incessant with modernization issues, the "uniqueness" in the Islamic boarding school environment makes the Islamic boarding school tradition more lively and interesting to be discussed. Environment Islamic boarding schools' implication in modern time is less known and marginal, which slowly change to be something interesting among scientists and academics. One of its pieces of evidence is the emergence of an idea from part of the Islamic education observers with a modern educational system to present alternative education discourse. It is in line with Islamic boarding schools whose progress is identical with Islamic education that experiences a transformation along with changes of accompanying situation.
\end{abstract}

Keywords: transformation; Islamic education; Indonesia

\section{INTRODUCTION}

Islamic education until now can felt still in a problematic position between "determinism histories" and "realism practical". On one side, Islamic education was not completely can out from the glory thought idealization and Islamic civilization in the past of hegemonic. While on the other, it also "forced" want to accept demands present time, especially coming from the West with an extremely practical orientation. In historical-empirical of plains, that reality often raises dualism and polarization education system on centre of Muslim community so that social transformation agenda rolled out as if it just functioned patchwork. Therefore, it is not surprising if on one side we still get a look "Islamic education system" that extremely traditional because still get a dress in the old fashion, while on another side we also get the "Islamic education system" materialistic and secularistic (Bektisiwi, 2019).

In this thing, usage makes an effort doing historical-philosophical research from Islamic education building, especially on third, fourth, and fifth-century pass critical analysis on thole organic basic structure epistemology dominant, cultural constellation, and the tradition of Islamic thought with education at that time, and implication of historical transformation on Indonesian Islamic education today. 


\section{METHOD}

This research belongs to the type of literature study research by finding relevant theory references related to the implementation of Islamic values in financial management. The theoretical references obtained by means of research literature studies serve as the basic foundation and the main tool for research practice in the middle of the field.

\section{RESULT AND DISCUSSION}

\section{Transformation Islamic Education In Indonesia}

\section{A. Condition Sketch and Islamic Boarding Potency}

The fact that Islam embraced by Indonesian residents majority, especially Java Islanders, can not release long process of Islamization that went through where Islamic boarding school intensively involved in it (Ambary, 1998) and even this institution becomes one of the main media Islamic influence in the moral formation of Indonesian nations (Karim, 2003). During a long process that Islamization, Islamic boarding schools have done accommodation with cautious policy and socio-culture transformation toward the pattern of local people's life. Islamic boarding schools are historically rated not only on a mission and contains Islamic nuance but also keep a feel of authenticity (Indigenous) of Indonesia because similar foundation built since Hindu and Buddhist times, while Islamic boarding schools just continue and Islamize (Raharjo, 1985).

There is an argument put forward by part of an educational historian as quoted Karel A. Steenbrink concerning the authenticity and origin of Islamic boarding school, that education system of Islamic boarding school similar to Hindu tradition (India), to remind all education are religious character; the teacher did not get a salary, much reverence toward the teachers (Kiai), and location of establishment the Islamic boarding schools so far from out of the city (Karel, 1994). However, it can be seen from Islamic nuances known with the Sufistic lessons and the pattern of teaching that began with the Arabic language lessons, there is true if Islamic boarding school considered being continuity from education systems of zawiya or khanaqah (Sufistic education system) in the middle East. Indirectly this thing is strengthened by the opinion most of the experts recognize of the big role Sufistics on early Islamization process Archipelago islands.

In historical records, had been appeared a suggestion from part of the founding fathers (the founders of Indonesia) to Islamic boarding school has an indigenous condensed characteristic that made national college alternative because rated has more advantage than what the things on West college. Advantages of Islamic boarding school there are: the first, boarding system makes it possible for the educator (Kiai) doing guidance and supervision directly to all students. Second, solidarity (personal relationship) between the student and educator (Kiai) extremely conducive for the acquisition of living knowledge. Third, the Islamic boarding schools ability to create graduates who have independence. Fourth, the simple life pattern of the Islamic boarding community. Fifth, cheap administration costs Islamic boarding school education (Raharjo, 1985). 
The assessment above does not just affirm. However, in general, the assessment indicates on some the side, Islamic boarding schools extremely the potential to develop become a religious institution, education, and community that is compatible in a culture of a nation. Even more, the Islamic boarding schools proven can be able to present themselves as an institution still exist on toward every form of social change dynamic with two main characteristics of education culture, that are (1) cultural character which allows the students to study completely, not only limit on the transfer of science but also personality formation aspect overall. (2) strength participation of society (Rahim, 2001). Because of that, extremely natural if Islamic boarding schools then many referenced, at least in early post-independence time, to be made as an alternative reference toward deadlock effort to formulate a national college system which is not scattered from Indonesian historical roots and also is not decrease efficiency and effectiveness.

The dynamics of the times go on while the modernization process is demanding Islamic boarding schools to accept change and development. However, is still there is a standard pattern as an essential thing in an environment of Islamic boarding schools that it rated relatively steady and continue related value system that is reflected in scientific tradition and morality (Madjid, 1997). Epistemically ethically recognized helped determine the perspective environment of Islamic boarding school interprets reality faced and gives reason its (Haidar, 1994). Just constancy and continuity are on that Islamic boarding schools, some on side precisely identified as caused the occurrence discrepancy between Islamic boarding schools and modernization steps on life in out of the environment. For example Nurcholish Madjid, in analysis its declared discrepancy of Islamic boarding school with modernization was not triggered by six things on generally still mark objective condition, that are:

1. Environment. Environment management of Islamic boarding schools, in general, is unplanned growth result, sporadic, and inadequate on quantity or quality. For example, the narrow bedrooms, the number of bathroom and the students was not comparable, irregular field, and disappointing worship place (prayer room/mosque).

2. The students. There is a discrepancy that displayed of the student compared with out of the environment, even about clothes, health, and behavior.

3. Curriculum. Teaching general science still halfway, dominant religious knowledge, less efficient teaching system, intellectualism, and excessive verbalism because oriented on productive reasoning, even prefer to raise dogmatism and principals.

4. Leadership. The certain benchmark in Islamic boarding school leadership, that are charisma, personal, religion-feudalism, and less concerned with technical skills. Some large Islamic boarding schools, as shown by Mastuhu research, still prefers to embrace charismatic leadership pattern with a style of "authoritarian-paternalistic".

5. Alumni. The alumni of Islamic boarding schools in general just compatible with "Traditional" society, and they prefer to reactive-aggressive toward out of an environment that wants not be able to compete in modern life. A traditional impression will always put 
down on Islamic boarding schools if the graduates do not have competitive abilities than the other graduates (Feisal, 1995).

6. Simplicity. Even though simplicity is recognized sticky with Islamic boarding school, this does still not get yet pressure in a curriculum. Because of that, probably simplicity Islamic boarding school is an escape from failure. Because of the simplicity also cause lead to management most of the Islamic boarding school less professional.

\section{B. Dynamic Style of Islamic Boarding Schools}

The advantages and disadvantages of the Islamic boarding school tradition are part of the nation's cultural treasures. It has a large contribution "indigenize" of Islam so easy digested and spared from the conflictual clash on early appear period and development local culture, through way inheritance tradition on the middle century and acculturation local culture. From this, continuity pattern and change pattern accommodative-transformative. Not just that, Islamic boarding schools are also recognized has been instrumental in growing community self-help and self-sufficiency (Mulkhan, 2002).

On that basis, Abdul Munir Mulkhan assumes Committee Reformation Education (KRP) fail for understanding Islamic boarding school because has been attached Islamic boarding school as a formal education foundation in school form and out of the school form. As seen on refinement academic manuscripts UUSPN arranged KRP. Those manuscipts declare "Islamic boarding School is Islamic education school track or out of school track" in an integrated manner on primary, secondary and high education". KRP need to differentiate Islamic boarding schools as education organizer then establish the schools, madrasas, and diniyah. Because, without a clear concept about cohesiveness school and out of schools in an environment the Islamic boarding schools, this thing can because the peculiarity of Islamic boarding schools on purpose, curriculum, system, and learning evaluation it eventually fades away.

Conceptualization of Islamic boarding school as formal education foundation school track and out of school, it means positioning government as must responsibility towards continuity Islamic boarding school on budget education. But conceptualization will change Islamic boarding school imagery as consistent of independent foundation use the strategic function in development community self-help and self-sufficiency.

Related to attitude towards out of environment (change), there is an assumption that Islamic boarding school "allergy" toward change. This assumption is have not reasoned and basic. Because, this last time dynamic Islamic boarding school proved has been many ways beyond first "definition" and function traditional, as Islamic foundation has a function for tafaqquh fi ad-din in narrow meaning and the Islamic boarding schools when just understood has to function to Islamic knowledge transmission, maintain Islam tradition and producing scholars.

Someplace have been appeared agriculture of Islamic boarding schools, the farm of Islamic boarding schools and its kind, as the result of innovative government policies toward Islamic 
boarding school institution or the result of acculturation Islamic boarding school with the demands of modernity. Nevertheless, not a little Islamic boarding school still clawed with a traditional pattern; Islamic boarding school directed as printing scholars foundation (Wahid, 1999).

The last development education system of Islamic boarding school has been experiencing a convergence process (Dhofier, 2001) and a little can classified into five types, that are: first, the Islamic boarding school organizes formal education to apply national curriculum, either just has religion school or has religion and general both school; second, the Islamic boarding school organizes religion education in madrasa and teaching general science even though not applying national curriculum' third, the Islamic boarding school just teaching religion science in diniyah; fourth, the Islamic boarding school just be recitation place; and fifth, the Islamic boarding school prepared for dorm students or general students.

Besides that, change of Islamic boarding schools also triggered many complaints from society indicated a decrease in their assessments (appreciations) toward Islamic boarding schools In reality, a change of Islamic boarding schools was recognized giving a vast and significant social impact. Even in the case in West Sumatra, as displayed by Azyumardi Azra, modern Islamic boarding school managed to appear as an institution that can raise a gloomy image that is already immersed in discourse and that education institutional (Azra, 2002).

When examined carefully until now, at the very least has been a change of two kinds (shift) inside of Islamic boarding school, that are function and management change (Nata, 2001). Meanwhile, the result of the analysis Azyurmadi Azra state that takes places of change in Islamic boarding schools in response to expansion general education systems have two ways that are, (1) revising the curriculum to enter many general subjects or even many general skills, and (2) opening the institutional and the education facilities to the importance the general education (Azra, 2002). But in general, the dynamic change that happened in Islamic boarding schools, either side of quantitative or qualitative as seen still slow (Dhofier, 2001). Especially with the main resistance has not been resolved about leadership, methodology, disorientation, and financing problems (Wahid, 1999).

The phenomenon of change and renewal that takes place in the Islamic boarding school is embodiment from spirit adage of popular in the Islamic boarding school tradition there are $A l$ muhafazhah ala al-qadim ash-shalih wa al-akhdhu bi al-jadid al-ashlah (maintain the value/ the better of old tradition and take the value/ the better of new tradition). This adage, a reflection of intellectual tradition the Islamic boarding school prefers to expert as a historical accident. Because of that, extremely strategic if some historical accidents are studied and developed as raw materials of a methodological structure delivery paradigmatic tradition of environment change. Therefore, such adage needs to be interpreted dynamically, creatively, and innovatively interpreted and developed to be public awareness, so that took place not the other way around, a trend to maintain the old concepts recognized have been tested (al-qadimi) more dominant (conservative, imitation) 
than an effort to actively-creatively take new concepts and better (al-jadid) and corresponding with the demands and the challenges of the times (Ijtihad; Tajdid) (Abdullah, 2002).

\section{Madrasa Dilemma: Institution and Education}

Islamic education reality in the homeland, when discussed the foundation of Islamic education apart of Islamic boarding school, so will be imagined in ourselves were the madrasa. This education institution was born in the early twentieth century, which can be recognized as a growth time the madrasa in the history of Islamic education in Indonesia. Many Indonesian Muslims starting to realize that they will not be able to compete with challenging powers from Dutch colonialism, Christian concentration, and struggle to advanced in other parts of Asia if they continue on the traditional event in affirming Islam.

The emergence of critical awareness among Indonesian Muslims can not be released from the gait of the educated Egyptian of education graduate or the Middle East that have been much absorbing their spirit of renewal (modernism). Otherwise, to the homeland, they do develop a new education institution which is commonly called madrasa applying a new method and curriculum. From this, it is not wondered if will happen some basic changes in dynamic Islam Indonesia which are at least pushed by four important factors, that are :

1. In some places of Islam environment appear strong a trend return to Qur'an and the hadith of the prophet made a starting point for assessing existing religious and cultural habits;

2. Flush and the nature of national resistance towards the ruler of Dutch colonial;

3. A strong effort from Islam to strengthen the organization in the socioeconomic field, for the benefits of themselves or of the people at large;

4. Islamic educational reform caused appear dissatisfaction with traditional patterns.

Related to it, the emergence of madrasa be seen by educational historians as one of Islamic education renewal in Indonesia. The argument can be argued that historically; the early emergence of the madrasa can return on two situations: first, there is a change in Islam, and second, responses of Islamic education toward the policy education of Dutch Eash Indies. Therefore, if it is seen from the viewpoint of Islamic boarding school so the presence of madrasa inviting a critical dimension because it is part of efforts the renewal to bridge traditional system held by the modern education system the Islamic boarding school. Besides that, the presence of madrasa is improvement efforts to Islamic boarding system toward an education system more likely the graduates obtain the same opportunities with general school. Meanwhile, if it is seen from the viewpoint of modern education colonial talent, the presence of madrasa contains an "acculturative" dimension because it is a manifestation and realization of the renewal of the Islamic education system that was wanted by part of Muslims who assume a positive system of Western education (Zuhairini, 1986).

In short, the growth of madrasa in the homeland is the result of tug between Islamic boarding schools as original education foundation (traditional) on one side, with Western education (modern) on the other side (Shaleh, 2004). At least, two trends can be identified from appearing the form of madrasa: first, the madrassas of Diniyyah-Salafiyah which continue to grow and 
develop with enhancement as well as quality reinforcement as tafaqquh fi ad-din foundations (that are solely oriented toward deepening religion) and second, the madrassas which are teaching science and Islamic values, also enter some of the material taught in schools held by Dutch East Indies government.

\section{CONCLUSION}

Concerning the authenticity and origin of Islamic boarding schools, thae education system of Islamic boarding school similar to Hindu tradition (India), to remind all education are religious character; the teacher did not get a salary, much reverence toward the teachers (Kiai), and location of establishment the Islamic boarding schools so far from out of the city. However, it can be seen from Islamic nuances known with the Sufistic lessons and the pattern of teaching that began with the Arabic language lessons, there is true if Islamic boarding school considered being continuity from education systems of zawiya or khanaqah (Sufistic education system) in the middle East. Indirectly this thing is strengthened by the opinion most of the experts recognize of the big role Sufistics on early Islamization process Archipelago islands.

In historical records, had been appeared a suggestion from part of the founding fathers (the founders of Indonesia) to Islamic boarding school has an indigenous condensed characteristic that made national college alternative because rated has more advantage than what the things on West college. Advantages of Islamic boarding school there are: the first, boarding system makes it possible for the educator (Kiai) doing guidance and supervision directly to all students. Second, solidarity (personal relationship) between the student and educator (Kiai) extremely conducive for the acquisition of living knowledge. Third, the Islamic boarding schools ability to create graduates who have independence. Fourth, the simple life pattern of the Islamic boarding community. Fifth, cheap administration costs Islamic boarding school education.

\section{REFERENCES}

Alan, R. L. B. (2004). Jihad Ala Pesantren di Mata Antropolog Amerika. Yogyakarta: Gama Media. Ali, M. H. (1994). NU dan Islam di Indonesia: Pendekatan fiqih dalam politik. Jakarta: Gramedia Pustaka. Amir, J. F. (1995). Reorientasi Pendidikan Islam. Jakarta: Gema Insani Press.

Azra, A. (2002). Paradigma Baru Pendidikan Nasional: Rekonstruksi dan Demokratisasi. Jakarta: Buku kompas.

Bektisiwi, P. (2019). Implementation of democratic values at the Jagad student boarding school 'Alimussirry Surabaya. Journal Intellectual Sufism Research (JISR), 1(2), 23-26.

Dawam, M. R.(ed). (1985) Pergaulan Dunia Pesantren; Membangun Dari Bawah. Jakarta: P3M Jabali, F and Jamhari (ad). (2002). IAIN dan Modernisasi Islam di Indonesia. Jakarta: Logos.

Karel, A. S. (1994) Pesantren Madrasah Sekolah: Pendidikan Islam dalam Kurun Modern. Jakarta : LP3ES

Madjid, N. (1997). Bilik-bilik Pesantren: Sebuah Potret Perjalanan. Jakarta: Paramadina. Maksum. (1999). Madrasah: Sejarah dan Perkembangannya. Jakarta: Logos Wacana Ilmu. 
Malik, A. F. (1999). Madrasah dan Tantangan Modernisasi. cet.II. Bandung:Mizan.

Muhaimin. (2003). Wacana Pengembangan Pendidikan Islam. Yogyakarta: Pustaka Belajar.

Rachman, A. S. (2004). Madrasah dan Pendidikan Anak Bangsa: Visi, Misi, dan Aksi. Jakarta: PT. Rajagrafindo Persada.

Rahim, H. (2001). Arah Baru Pendidikan Islam di Indonesia. Jakarta: Logos.

Usa, M. \& Wijdan, A. S. Z. (ad). (1997). Pendidikan Islam dalam peradaban Industrial. Yogyakarta: Aditya Media.

Tilaar, H.A.R. (2000). Paradigma Baru Pendidikan Nasional. Jakarta: Rineka Cipta.

Wahid, A. (1999). Prisma Pemikiran Gus Dur. Yogyakarta: LKiS.

Wahjoetomo. (1997). Perguruan Tinggi Pesantren: Pendidikan Tinggi Alternatif Masa Depan. Jakarta: Gema Insan Press

Zuhairini, etc. (1986). Sejarah Pendidikan Islam di Indonesia Jakarta: Proyek Pembinaan Prasarana dan Sarana PTA Dirjen Binbaga DEPAG. 